Journal of Economics and Behavioral Studies

Vol. 4, No. 8, pp. 457-466, Aug 2012 (ISSN: 2220-6140)

\title{
A Study of the Returns Behavior of Small Capitalization REITs
}

\author{
Sanjay Rajagopal*, Patrick A. Hays \\ Western Carolina University Cullowhee, NC \\ *rajagopal@email.wcu.edu
}

\begin{abstract}
We analyze the daily returns on 63 real estate investment trusts (REITs) that comprise five US Small Cap REIT indices, and test for weak-form efficiency by estimating the Hurst exponent and fractal dimension. Fourteen of the 63 firms (or roughly 22\% of the firms studied) fail to exhibit weak-form efficiency, based on Classical Rescaled Range Analysis. Two additional self-affine fractal analysis techniques (Roughness-Length and Variogram analyses) provide some support for this finding. In particular, it is found that a majority of the series for which weak-form efficiency is rejected are anti-persistent, with estimated Hurst exponents below 0.50.These results are further confirmed by Lo's (1991) modified rescaled range analysis, which reveals significant memory at long lags. Overall, the results suggest inefficient pricing for a significant subset of REITs, with important implications for trading and for the modeling of REIT returns. .Some aspects of their returns behavior warrant further study.
\end{abstract}

Keywords: Investment returns, small capitalization, REITs

\section{Introduction}

An enduring topic of interest in the study of returns and volatility behavior of various economic and financial time series has been the possibility of long memory, or autocorrelation over long lags (e.g., Diebold \& Rudebusch, 1989; Lo, 1991; Ding et al., 1993; Baillie, 1996; Mulligan, 2000; Cotter \& Stevenson, 2008; Hays et al., 2010). Of the number of studies that have tested for the existence of long memory in stock returns, the more recent provide evidence that is inconsistent with weak-form efficiency in pricing. Hays et al. (2010), for example, find significant long memory in returns on the S\&P 500 and NASDAQ indices over a period that includes the 1992-2002 "tech bubble". Mulligan (2004) and Mulligan\& Banerjee (2008) find substantial evidence of anti-persistence in the returns series for technology stocks in the U.S. and India. These findings are in contrast to those of earlier studies such as Lo (1991) that did not find significant evidence of long memory during periods that pre-date the "tech bubble" of the 1990s. Added to this recent evidence pertaining to the general stock market is that fact that several studies find a shared set of risk factors that link real estate investment trusts (REITs) and the general stock market (e.g., Chan et al., 1990; Myer \& Webb, 1993; Glascock et al, 2000; and Okunev et al, 2000). Taken together, these two sets of findings raise the question as to whether REIT return series also possess long memory characteristics. Payne \& Waters (2007) suggest that REITs provide a natural case for the study of price behavior. This is so not only on account of their observed integration with the general stock market, but also because REIT markets are not liquid enough to support the increased short selling that normally would occur, for instance, when a market is overvalued. This latter feature might tend to weaken equilibrating forces that stave off the formation of bubbles, for example. In comparison to studies relating to the stock market in general, the study of efficiency within the REIT sector is in its nascent stages. In addition, there is no clear consensus among existing studies of the pricing efficiency of REITs. For instance, studies by Lee \& Chiang (2004) and Jirasakuldech \& Knight (2005) support the notion of efficient pricing, while those by Nelling\& Gyourko (1998) and Kuhle \& Alvayay (2000), suggest the contrary. The present study seeks to contribute to the growing literature on REIT returns behavior by employing fractal analysis to study persistence and anti-persistence in small capitalization REITs. Our results are consistent on some points with those of a recent study of long memory in REIT returns by Anoruo \& Braha (2010).However, the methodologies and data series employed by the two studies are different. The Anoruo \& Braha (2010) study considers four series of returns, viz., returns on four portfolios of REITs classified as "composite", "equity", "mortgage", and "hybrid". In contrast, we consider data at a more disaggregated level, analyzing 63 individual REIT returns series that relate to component firms of five NASDAQ REIT indices covering the "mortgage", "specialty", "industrial and office", "retail", and "residential" classifications. 
We do this because individual investors and traders would be interested in the returns behavior of indices as well as of individual securities. A second important distinguishing characteristic of our study is the fact that we focus on small capitalization REITs. Our choice of small cap REITs is motivated by the theoretical consideration that the price adjustment process might be quite different for small and large firms. Investors might possess less information about smaller firms (Atiase, 1985), the stocks of such firms might be less liquid, and transactions costs for trades, especially short sales, are likely higher for smaller capitalization firms (Brent et al., 1990; Brent et al., 1990; D’Avolio, 2002; Palmon et al., 2008). From an empirical standpoint, Pyles (2009), for example, documents a seasonal component to REITs returns that can be linked to behavioral factors, but which is driven by the smallest $40 \%$ of the REITs. In addition, the Lin et al. (2009) study of investor sentiment and REIT returns suggests that the return generating process is different for smaller versus larger REITs. Thus, focusing on small cap index components yields a more homogeneous set of firms whose pricing is also more likely to be affected by behavioral factors. A third point of distinction for our study is that we adopt an alternative approach to testing for long memory. While Anoruo \& Braha (2010) apply wavelets analysis and the Geweke and Porter-Hudak (1983) fractional integration method to test for long memory, we test for the presence of long memory by using the Classical Rescaled-Range (R/S) methodology proposed by Mandelbrot (1972) to estimate the Hurst exponent (H) and fractal dimension. The seminal study of REIT returns by Ambrose et al. (1992) employed this methodology, along with its modification suggested by Lo (1991), but this predated the long expansion of the 1990s, and the two major market upheavals of the last decade. In addition, in the case of those REITs for which classical R/S analysis suggests long memory, we examine fractal structure through two additional self-affine fractal analysis techniques (Roughness Length and Variogram/Structure Function methods). More recent studies that employ these fractal analysis techniques include Mulligan (2004), Mulligan \& Banerjee (2008), and Rajagopal \& Hays (2012).Lo's (1991) modified rescaled range analysis is also applied to the returns series that the classical R/S methodology indicates possess long memory. As noted by Lo (1991), the modified rescaled range method is robust with respect to short-term dependence (auto-correlation), non-normality, and hetero skedasticity that might detract from the accuracy of classical fractal analysis techniques. Finally, our study extends the time frame for analysis by almost four years past Anoruo \& Braha (2010). Thus, our data set covers a wider window to include the post financial crisis period.

Evidence of persistence or anti-persistence would tend to support the notion that behavioral factors play an important role in the pricing of assets. Apart from contributing to the literature on market efficiency in general, and pricing efficiency of REITs in particular, the present study also has practical implications Evidence of persistence or anti-persistence would tend to support the notion that behavioral factors play an important role in the pricing of assets. Apart from contributing to the literature on market efficiency in general, and pricing efficiency of REITs in particular, the present study also has practical implications for trading, and for the modeling of REIT returns. The presence of long memory in REITs would imply that inefficiencies in this segment of the market might allow the investor superior returns on a risk-adjusted basis. For example, technical analysts may attempt to exploit the existence of long-range dependence by defining trading rules that include higher-order moving averages (Sadique \& Silvapulle, 2001). Also, incorporating the long memory feature of time series can improve forecast accuracy (e.g., Choi \& Hammoudeh, 2009) for trading, and for the modeling of REIT returns. The presence of long memory in REITs would imply that inefficiencies in this segment of the market might allow the investor superior returns on a risk-adjusted basis. For example, technical analysts may attempt to exploit the existence of long-range dependence by defining trading rules that include higher-order moving averages (Sadique \& Silvapulle, 2001). In addition, incorporating the long memory feature of time series can improve forecast accuracy (e.g., Choi \& Hammoudeh, 2009). The remainder of the paper is organized as follows. In the next section, we provide a brief review of the literature. We then describe the study's methodology and data. The results of the classical R/S analysis, and, for 14 REITs, additional results from the Roughness Length, Variogram/Structure Function, and Lo's (1991) modified R/S methods are then presented. The paper ends with a discussion of the results and their implications.

\section{Literature Review}

This section describes the existing literature that provides the context for the present study. It begins with a brief account of the variety of time series to which long memory tests have been applied. Next, it reviews 
some of the studies of long memory in stock returns and volatility in particular. Finally, the current state of the literature on long memory in REIT returns is described, and the nature of the present study's contribution is discussed within that context. The last decade has seen a growing interest in the study of possible long memory features in various economic and financial time series. Overall, results pertaining to the existence of long memory in these series are mixed. Elder \& Jin (2009), for example, find some evidence of antipersistence in agricultural commodities futures, but no long memory in metals futures. Cunado et al. (2010) study energy futures markets, finding strong evidence of long memory in volatility but not in returns. Alptekin (2008) employs both Classical and Lo's (1991) Modified Rescaled Range analysis to find evidence of long memory in gold returns. Mulligan (2000) finds significant long memory in the foreign exchange markets for 22 countries, and Assaf (2004) indicates the absence of this feature in the real exchange rate series for the 8 countries in his study. Gschwandtner \& Hauser (2008) observe long-range dependence in profit series, and Kumar \& Okimoto (2007) find evidence of (declining) persistence in inflation for a majority of the G7 countries. Meade \& Maier (2003) find evidence of long memory in short term rates in 7 of the 10 countries they study, and Connolly et al (2007) find strong long memory in U.S. Treasury yields and term premiums. Similarly, numerous studies have investigated long memory in stock returns, and here too results have been mixed. In his seminal work using the modified rescaled range methodology, Lo (1991) did not find evidence of long memory in U.S. stock returns, a result consistent with the findings of Ambrose et al (1993) and Howe et al (1999).. Ding et al (1993 do find evidence of dependence in volatility measures over long lags. Assaf (2008) also finds evidence of long memory in the volatility of returns in the U.S. and German equity markets. Hays et al (2010),whose study spans the period of the "tech bubble" of the 1990s, find strong evidence of long memory in the returns for the NASDAQ and the S\&P500 indices, though not in returns on the Dow Jones. Studying these three indices over a period of between 36 and 56 years, Caporale \& Gil-Alana (2010) also find some evidence of long-range dependence.

Pricing inefficiencies and long memory also be the subject of study in the context of REITs, and here again results have been mixed. The Kuhle \& Alvayay (2000) study finds evidence of inefficient pricing in the equity REITs market. In contrast, Jirasakuldech \& Knight (2005) find REITs returns to exhibit weak-form efficient behavior. These latter results are consistent with those of Lee \& Chiang (2004), who study the relative behavior of equity and mortgage REITs, and find their returns to be random walk processes. With regard to the general question of pricing efficiency in REITs, the presence of a momentum effect in REIT returns is documented by Chui et al (2003) and Derwall et al (2009). Chui et al (2003) find that past REIT returns can be employed to predict future returns, and that a strategy of "buying winners and selling losers" can provide significant abnormal returns. According to their study, this momentum effect appears stronger than that for other market sectors. Derwall et al (2009) find that much of the "abnormal returns" of actively managed REIT funds dissipates once the REIT momentum effect is taken into account, challenging the notion that superior returns on such funds could be attributed to the skills of the fund managers. Studies of long memory in REITs have usually focused on indices of REIT returns, and have found long memory in return volatility (rather than in returns per se). Cotter and Stevenson (2008) find persistence in the volatility of REITs, though the magnitude is somewhat less than that for the S\&P 500. Volatility persistence is also found in various international real estate securities markets spanning the US, Asia, and the Pacific by Liow $(2007 ; 2009)$. In contrast to these studies that report long memory in volatility, Anoruo and Braha (2010) find evidence of long memory in returns for four indices covering the composite, equity, mortgage, and hybrid REIT subsectors. Similarly, Rajagopal \& Hays (2012) study Indian real estate equities and find evidence of long memory in returns. The study of Canadian REITs and stocks by Assaf (2006) documents long co-memories between the real estate securities and general stock markets. The present study extends this literature by documenting the presence of long-range dependence in the returns of several individual REITs rather than in broad indices. Further, as noted above, we focus on small capitalization REITs because theory suggests that the price adjustment process might be quite different for smaller firms. The market likely possesses less information about smaller firms (Atiase, 1985). In addition, stocks of smaller firms might be less liquid, and transactions costs for trades, especially short sales, likely higher for such firms (Brent et al., 1990; Brent et al., 1990; D'Avolio, 2002; Palmon et al., 2008). Overall, then, we seek to contribute to an area of study that is in a nascent stage, and in which mixed evidence is found with regard to the presence of long memory specifically in equity returns. The study of long memory is important from the practical viewpoint of traders and forecasters, since such long-range dependence suggests the potential for abnormal profits if the dependence can be modeled adequately. The area of study is significant also from a theoretical perspective. Specifically, 
the presence of long memory in financial time series poses a challenge to the notion of efficient markets that has formed the basis for traditional theoretical finance, and suggests the need for behavioral models.

\section{Methodology}

Five US Small Cap REIT indices quoted on the NASDAQ were identified: the US Small Cap Mortgage REITs $\left({ }^{\wedge}\right.$ NQUSS8676), the US Small Cap Specialty REITs (^NQUSS8675), the US Small Cap Industrial \& Office REITs $\left({ }^{\wedge}\right.$ NQUSS8671), the US Small Cap Retail REITs ( ${ }^{\wedge}$ NQUSS8672), and the US Small Cap Residential REITs $\left({ }^{\wedge}\right.$ NQUSS8673). For each of the REITs that comprise these indices, the entire series of daily-adjusted closing prices available as of April 30, 2012 were collected from finance.yahoo.com. There were 63 REITs within these indices that had daily data spanning at least five years, and these were included in our study. We began by employing Mandelbrot's (1972) classical rescaled-range (R/S) analysis to estimate the self-affinity index (Hurst exponent, $\mathrm{H}$ ) of the returns series for the 63 individual REITs from the five indices. For the 14 REITs that indicate persistence or anti-persistence, the Roughness Length $(\mathrm{R} / \mathrm{L})$, and the Variogram/Structure Function methods were also applied in the estimation of the fractal dimension. Finally, for this subset of REITs, Lo's (1991) modified R/S analysis was used to test for long memory at various lags. All four methodologies are described below.

Classical R/S Analysis: Hurst's (1951) seminal study of the Nile River ${ }^{1}$ forms the basis for the Classical R/S analysis. The mean and standard deviation of a time series, $\mathrm{x}_{\mathrm{m}}$, and $\mathrm{s}_{\mathrm{n}}$ are first calculated. Next, the difference between the maximum and minimum cumulative deviation values over the $\mathrm{n}$ observations is defined as the range, $\mathrm{R}$ :

$$
\mathrm{R}=\operatorname{Max}\left[\sum_{\mathrm{i}=1}^{\mathrm{n}}\left(\mathrm{x}_{\mathrm{i}}-\mathrm{x}_{\mathrm{m}}\right)\right]-\operatorname{Min}\left[\sum_{\mathrm{i}=1}^{\mathrm{n}}\left(\mathrm{x}_{\mathrm{i}}-\mathrm{x}_{\mathrm{m}}\right)\right]
$$

The range can be thought of as the distance that the system travels in time $\mathrm{n}$, which, for systems following Brownian motion, is proportional to the square root of time, $\mathrm{T}$ :

$\mathrm{R}=\mathrm{T}^{0.50}$

The following is a generalized form of this rule for time series characterized by dependence rather than Brownian motion (Hurst, 1951):

$$
\frac{\mathrm{R}}{\mathrm{s}_{\mathrm{n}}}=\mathrm{k} \times \mathrm{n}^{\mathrm{H}}
$$

This expression relates the range scaled by the standard deviation of the series ("rescaled range"), to the "Hurst exponent", H. k represents a constant. The relationship describes how the range of the cumulated deviations from mean scales over the time increment, $\mathrm{n}$; for a random time series, $\mathrm{H}$ would be 0.50 .

The logarithm of the above expression yields:

$$
\log \left(\frac{\mathrm{R}}{\mathrm{S}_{\mathrm{n}}}\right)=\log \mathrm{k}+\mathrm{H} \log \mathrm{n}
$$

The Hurst exponent is then estimated as the slope of the plot of $\log R / s_{n}$ against $\log n$. If $0.50<H \leq 1$, then the series is "persistent"-elements in the series influence other elements in the series. If $0 \leq \mathrm{H}<0.50$, then the series is "anti-persistent", and the process reverses itself more frequently than would a random process.

Roughness-Length and Variogram Methods: The Roughness-Length (R/L) method is akin to the classical $\mathrm{R} / \mathrm{S}$ analysis, with the difference that, in place of the $\mathrm{R} / \mathrm{S}$, it employs the root-mean-square roughness of the data in windows of length $\mathrm{w}, \mathrm{S}(\mathrm{w})$. This roughness variable is related to the Hurstexponent thus:

$\mathrm{S}(\mathrm{w}) \approx \mathrm{wH}$.

The variogram, or "variance of increments"/structure function $(S / F)$, of a series $y(x)$ is:

$\mathrm{V}(\mathrm{w}) \equiv[\mathrm{y}(\mathrm{x})-\mathrm{y}(\mathrm{x}+\mathrm{w})]^{2}$

\footnotetext{
${ }^{1}$ For recent use of R/S analysis to study equity returns behavior, see Mulligan (2004) and Mulligan \& Banerjee (2008).
} 
where $\mathrm{w}$ is the distance between two $\mathrm{y}$ values in a trace. The variogram is related to the Hurst exponent as (see, for example, Mulligan, 2004):

$\mathrm{V}(\mathrm{w}) \approx \mathrm{w}^{2 \mathrm{H}}$

The Roughness-Length and Variogram methods also use regression to estimate the Hurst exponent.

Lo's Modified R/S Analysis: In contrast to the classical R/S described above, the MRS proposed by Lo (1991) is:

$$
\mathrm{Q}_{\mathrm{n}}=\frac{\mathrm{R}_{\mathrm{n}}}{\mathrm{S}_{\mathrm{t}}}
$$

$\mathrm{S}_{\mathrm{t}}$ is derived from a variance estimator based on the sum of the sample variance plus a weighted sum of the auto-covariance terms up to lag q:

$$
\mathrm{S}_{\mathrm{t}}^{2}=\mathrm{S}_{\mathrm{x}}^{2}+\frac{2}{\mathrm{n}} \sum_{\mathrm{j}=1}^{\mathrm{q}} \mathrm{w}_{\mathrm{j}}(\mathrm{q}) \mathrm{C}_{\mathrm{j}}
$$

where:

$\mathrm{S}_{\mathrm{x}}^{2}=$ sample variance,

$\mathrm{C}_{\mathrm{j}}=$ auto covariance term for lag $\mathrm{j}$

$=\sum_{i=j+1}^{n}\left(r_{i}-r_{m}\right)\left(r_{i-j}-r_{m}\right)$

$\mathrm{w}_{\mathrm{j}}(\mathrm{q})=$ Newey-West (1987) weighting factor for $C_{j}$

$=1-\frac{\mathrm{j}}{(\mathrm{q}+1)}, \mathrm{q}<\mathrm{n}$.

The test for long-term dependence is conducted using the $Q_{n}$ statistic adjusted for observations:

$$
\mathrm{V}_{\mathrm{n}}=\frac{\mathrm{Q}_{\mathrm{n}}}{\sqrt{\mathrm{n}}}
$$

The formulation of the variance estimator makes the method robust with respect to short-term dependence (auto-correlation), non-normality, and hetero skedasticity. Lo (1991) derives the limiting distribution of the modified statistic, which we used to calculate the p-values for Vn, and checked those calculations against the critical values supplied in Lo's study².

\section{Results \& Discussion}

The paucity of information for smaller firms may cause the market to overreact to any arrival of information (see, for example, Wang \& Xie, 2010), tending to make the return series anti-persistent. On the other hand, Peters (1994) suggests that returns can trend in a given direction due to "market sentiment" or "bias" until some exogenous event changes that bias. This may induce long-term persistence in returns. We are left with no theoretical a priori expectation with regard to the specific behavior of the small cap REIT returns, and the precise nature of potential departures from efficient pricingre mains largely an empirical issue. To study return behavior, we first conducted Classical R/S analysis for each of the 63 REITs in the sample. Fourteen of these REITs (or roughly $22 \%$ of the sample) yielded estimated Hurst exponents that were significantly different from 0.50. For this subset of 14 REITs, additional tests based on Roughness Length (R/L) and the Variogram/Structure Function (S/F) methods were conducted. In the interest of brevity, Classical R/S results for all 63 firms are not included here, and Table 1 shows the results only for those 14 REITs which the classical R/S analysis first showed as possessing either persistence or anti-persistence.

\footnotetext{
${ }^{2}$ Some recent studies employing the Lo (1991) methodology include Cotter \& Stevenson (2008) and Hays et al (2010).
} 
Table 1: Results of R/S, R/L, and S/F Methods: Selected REITs

\begin{tabular}{lllllll}
\hline REIT & H & se & t & Method & Signif & \#Obs \\
\hline Armour & 0.489 & 0.006 & 1.897 & $\mathrm{R} / \mathrm{S}$ & $*$ & 1109 \\
(Mortgage) & 0.511 & 0.004 & 2.500 & $\mathrm{R} / \mathrm{L}$ & $* *$ & 1109 \\
& 0.441 & 0.170 & 0.347 & $\mathrm{~S} / \mathrm{F}$ & --- & 1109 \\
Capstead & 0.547 & 0.011 & 4.476 & $\mathrm{R} / \mathrm{S}$ & $* * *$ & 5624 \\
(Mortgage) & 0.504 & 0.008 & 0.476 & $\mathrm{R} / \mathrm{L}$ & --- & 5624 \\
& 0.564 & 0.147 & 0.434 & $\mathrm{~S} / \mathrm{F}$ & -- & 5624 \\
Dynex & 0.523 & 0.013 & 1.783 & $\mathrm{R} / \mathrm{S}$ & $*$ & 5621 \\
(Mortgage) & 0.463 & 0.007 & 5.286 & $\mathrm{R} / \mathrm{L}$ & $* * *$ & 5621 \\
& 0.641 & 2.360 & 0.060 & $\mathrm{~S} / \mathrm{F}$ & --- & 5621 \\
Hatteras & 0.438 & 0.011 & 5.487 & $\mathrm{R} / \mathrm{S}$ & $* * *$ & 1007 \\
(Mortgage) & 0.371 & 0.002 & 58.636 & $\mathrm{R} / \mathrm{L}$ & $* * *$ & 1007 \\
& 0.373 & 0.028 & 4.472 & $\mathrm{~S} / \mathrm{F}$ & $* * *$ & 1007 \\
MFA Fin & 0.477 & 0.011 & 2.072 & $\mathrm{R} / \mathrm{S}$ & $* *$ & 3528 \\
(Mortgage) & 0.403 & 0.004 & 26.216 & $\mathrm{R} / \mathrm{L}$ & $* * *$ & 3528 \\
& 0.438 & 0.062 & 1.002 & $\mathrm{~S} / \mathrm{F}$ & -- & 3528 \\
CubeSmart & 0.543 & 0.012 & 3.525 & $\mathrm{R} / \mathrm{S}$ & $* * *$ & 1880 \\
(Specialty) & 0.466 & 0.016 & 2.112 & $\mathrm{R} / \mathrm{L}$ & $* *$ & 1880 \\
& 0.579 & 0.062 & 1.276 & $\mathrm{~S} / \mathrm{F}$ & -- & 1880 \\
Extra Space & 0.457 & 0.023 & 1.903 & $\mathrm{R} / \mathrm{S}$ & $*$ & 1941 \\
(Specialty) & 0.402 & 0.005 & 19.216 & $\mathrm{R} / \mathrm{L}$ & $* * *$ & 1941 \\
& 0.514 & 0.304 & 0.046 & $\mathrm{~S} / \mathrm{F}$ & -- & 1941 \\
Cap Lease & 0.452 & 0.022 & 2.222 & $\mathrm{R} / \mathrm{S}$ & $* *$ & 2043 \\
(Ind/Office) & 0.390 & 0.007 & 16.667 & $\mathrm{R} / \mathrm{L}$ & $* * *$ & 2043 \\
& 0.533 & 0.248 & 0.133 & $\mathrm{~S} / \mathrm{F}$ & --- & 2043 \\
DCT Ind & 0.344 & 0.051 & 3.083 & $\mathrm{R} / \mathrm{S}$ & $* * *$ & 1352 \\
(Ind/Office) & 0.337 & 0.001 & 148.182 & $\mathrm{R} / \mathrm{L}$ & $* * *$ & 1352 \\
& 0.426 & 0.303 & 0.245 & $\mathrm{~S} / \mathrm{F}$ & --- & 1352 \\
\hline & & & & & &
\end{tabular}

***Significant at $\alpha=1 \%$ **Significant at $\alpha=5 \%$ *Significant at $\alpha=10 \%$

These results suggest that most of the series exhibit anti-persistence, with estimated Hurst exponents typically below 0.5 . The roughness length method tends to confirm the results of the classical R/S analysis, but the variogram/structure-function method suggests a rejection of the null only in the case of Hatteras. To further investigate the issue of long-term dependence in the 14 series, Lo's MRS analysis was conducted for numerous lag lengths, the results of which are summarized in Table 2 below. Interestingly, the results suggest the presence of dependence at very long lags. To keep length manageable, the table reports only those lags for which long memory was detected, and shows the results for ranges of lag lengths. The MRS analysis reveals that, with the exception of Cubesmart and Cap lease, a long memory effect is observed at somewhat longer lag lengths (of roughly sixty trading days or more). Overall, the results of the Classical R/S, Roughness Length, Variogram/Structure Function, and Modified R/S methods indicate pricing inefficiencies in a significant subset (22\%) of the REITs comprising the five small capitalization REIT indices studied. These results we find for individual small capitalization REITs are consistent with those of Anoruo \& Braha (2010), who use semi-parametric and wavelet estimators to study the long memory characteristics of "composite", "equity", "mortgage", and "hybrid" REIT index returns. They find their returns series to be anti-persistent, as we do for a majority of the individual small capitalization in our subsample. The following section discusses the implications of this result, and points to avenues of future research. 
Table 1 (contd.): Results of R/S, R/L, and S/F Methods: Selected REITs

\begin{tabular}{lllllll}
\hline REIT & H & se & t & Method & Signif & \#Obs \\
\hline Monmouth & 0.389 & 0.021 & 5.362 & $\mathrm{R} / \mathrm{S}$ & $* * *$ & 5570 \\
(Ind/Office) & 0.270 & 0.007 & 34.328 & $\mathrm{R} / \mathrm{L}$ & $* * *$ & 5570 \\
Cedar & 0.420 & 1.169 & 0.068 & $\mathrm{~S} / \mathrm{F}$ & --- & 5570 \\
Realty & 0.524 & 0.005 & 5.106 & $\mathrm{R} / \mathrm{S}$ & $* * *$ & 2229 \\
(Retail) & 0.507 & 0.009 & 0.795 & $\mathrm{R} / \mathrm{L}$ & --- & 2229 \\
Inland & 0.423 & 0.617 & 0.125 & $\mathrm{~S} / \mathrm{F}$ & --- & 2229 \\
(Retail) & 0.444 & 0.017 & 1.677 & $\mathrm{R} / \mathrm{S}$ & $*$ & 1989 \\
& 0.441 & 0.007 & 8.116 & $\mathrm{R} / \mathrm{L}$ & $* * *$ & 1989 \\
Urstadt- & 0.404 & 0.031 & 3.067 & $\mathrm{R} / \mathrm{S}$ & $* * *$ & 3449 \\
UBA & 0.331 & 0.002 & 88.947 & $\mathrm{R} / \mathrm{L}$ & $* * *$ & 3449 \\
(Retail) & 0.354 & 0.244 & 0.599 & $\mathrm{~S} / \mathrm{F}$ & --- & 3449 \\
Urstadt- & 0.431 & 0.021 & 3.224 & $\mathrm{R} / \mathrm{S}$ & $* * *$ & 6107 \\
UBP & 0.392 & 0.004 & 26.341 & $\mathrm{R} / \mathrm{L}$ & $* * *$ & 6107 \\
(Retail) & 0.427 & 0.566 & 0.129 & $\mathrm{~S} / \mathrm{F}$ & --- & 6107 \\
\hline
\end{tabular}

${ }^{* * *}$ Significant at $\alpha=1 \% * *$ Significant at $\alpha=5 \%$ *Significant at $\alpha=10 \%$

\section{Conclusion}

The evidence of long memory documented in this study suggests that, at least in the case of a significant subset of REITs, weak form efficiency does not apply. These results have important implications for trading and for REIT return modeling. The presence of long memory indicates that inefficiencies in this segment can allow the investor superior risk-adjusted returns, since it suggests that past information can be exploited to predict future returns. Technical analysts could conceivably exploit the existence of the long-range dependence feature by devising trading rules that include higher-order moving averages (Sadique \& Silvapulle, 2001).Furthermore, incorporating the long memory characteristic is likely to improve forecast accuracy). In particular, non-linear models may provide superior forecasts to traditional linear modeling of returns at least for a significant number of REITs. Long memory in time series would adversely affect the accuracy of inferences and forecasts relying on traditional linear models employing the independence assumption. Instead, ARFIMA models in which correlations decay exponentially rather than hyperbolically may help enhance forecast accuracy (see, for example, Choi \& Hammoudeh, 2009). Our results suggest a couple of potential areas for further research. Studying possible behavioral factors that result in a long memory effect in REIT returns would represent one line of enquiry. Moreover, the fact that dependence in returns is observed at fairly long lags for most of the REITs in the subsample warrants further study. Specifically, future research might seek to ascertain what behavioral attributes of REIT investors likely contribute to such a feature. Finally, it is noteworthy that the incidence of long-range dependence appears to be higher among mortgage REITs, the explanation of which feature also calls for further study.

Table 2: Modified R/S Analysis Results: Selected REITs

\begin{tabular}{lllll}
\hline REIT & Lag & $\mathbf{V}_{\mathbf{n}}$ & $\mathbf{p}$ & Sig \\
\hline Armour & $288-403$ & $1.619-1.745$ & $0.100-0.050$ & $*$ \\
(Mortgage) & $404-702$ & $1.748-2.000$ & $0.049-0.010$ & $* *$ \\
& $703-1038$ & $2.001-2.387$ & $0.009-0.000$ & $* * *$ \\
Capstead & $1041-1139$ & $1.619-1.746$ & $0.100-0.050$ & $*$ \\
(Mortgage) & $1140-1346$ & $1.747-2.000$ & $0.049-0.010$ & $* *$ \\
& $1347-1805$ & $2.001-2.278$ & $0.009-0.000$ & $* * *$ \\
\hline
\end{tabular}




\begin{tabular}{|c|c|c|c|c|}
\hline $\begin{array}{l}\text { Dynex } \\
\text { (Mortgage) }\end{array}$ & $\begin{array}{l}791-914 \\
915-1086 \\
1087-2178\end{array}$ & $\begin{array}{l}1.619-1.746 \\
1.747-2.000 \\
2.002-3.202\end{array}$ & $\begin{array}{l}0.099-0.050 \\
0.049-0.010 \\
0.009-0.000\end{array}$ & $\begin{array}{l}* \\
* * \\
* * *\end{array}$ \\
\hline $\begin{array}{l}\text { Hatteras } \\
\text { (Mortgage) }\end{array}$ & $\begin{array}{l}67-111 \\
112-202 \\
203-671\end{array}$ & $\begin{array}{l}1.622-1.745 \\
1.751-1.999 \\
2.001-3.361\end{array}$ & $\begin{array}{l}0.099-0.051 \\
0.049-0.010 \\
0.009-0.000\end{array}$ & $\begin{array}{l}* \\
* * \\
* * *\end{array}$ \\
\hline $\begin{array}{l}\text { MFA Fin } \\
\text { (Mortgage) }\end{array}$ & $\begin{array}{c}1307-1386 \\
1387-1536 \\
1537-2044\end{array}$ & $\begin{array}{l}1.620-1.746 \\
1.748-2.000 \\
2.001-2.642\end{array}$ & $\begin{array}{l}0.099-0.050 \\
0.049-0.010 \\
0.010-0.000\end{array}$ & $\begin{array}{l}* \\
* * \\
* * *\end{array}$ \\
\hline $\begin{array}{l}\text { Cubesmart } \\
\text { (Specialty) }\end{array}$ & $\begin{array}{l}1-46 \\
47-99 \\
151-203 \\
204-600 \\
601-1877\end{array}$ & $\begin{array}{l}1.771-1.939 \\
1.622-1.744 \\
1.620-1.744 \\
1.747-1.999 \\
2.002-3.251\end{array}$ & $\begin{array}{l}0.044-0.015 \\
0.098-0.050 \\
0.051-0.099 \\
0.049-0.010 \\
0.010-0.000\end{array}$ & $\begin{array}{l}* * \\
* \\
* \\
* * \\
* * *\end{array}$ \\
\hline $\begin{array}{l}\text { Extra Space } \\
\text { (Specialty) }\end{array}$ & $\begin{array}{l}24-54 \\
55-100 \\
101-227 \\
228-449 \\
450-581 \\
582-1159 \\
1160-1938\end{array}$ & $\begin{array}{l}1.626-1.740 \\
1.747-1.748 \\
1.745-1.746 \\
1.748-1.747 \\
1.746-1.746 \\
1.747-2.000 \\
2.001-2.568\end{array}$ & $\begin{array}{l}0.097-0.052 \\
0.050-0.049 \\
0.051-0.050 \\
0.049-0.050 \\
0.050-0.050 \\
0.050-0.010 \\
0.009-0.000\end{array}$ & $\begin{array}{l}* \\
* * \\
* \\
* * \\
* \\
* * \\
* * *\end{array}$ \\
\hline $\begin{array}{l}\text { Cap Lease } \\
\text { (Ind/Office) }\end{array}$ & $\begin{array}{l}11-59 \\
109-219 \\
220-497 \\
498-1336\end{array}$ & $\begin{array}{l}1.625-1.622 \\
1.620-1.746 \\
1.747-2.000 \\
2.001-2.986\end{array}$ & $\begin{array}{l}0.097-0.099 \\
0.099-0.050 \\
0.049-0.010 \\
0.009-0.000\end{array}$ & $\begin{array}{l}* \\
* \\
* * \\
* * *\end{array}$ \\
\hline $\begin{array}{l}\text { DCT Ind } \\
\text { (Ind/Office) }\end{array}$ & $\begin{array}{l}57-69 \\
70-89 \\
90-196 \\
197-290\end{array}$ & $\begin{array}{l}1.626-1.746 \\
1.758-1.750 \\
1.742-1.745 \\
1.747-1.917\end{array}$ & $\begin{array}{l}0.096-0.050 \\
0.047-0.049 \\
0.051-0.050 \\
0.050-0.017\end{array}$ & $\begin{array}{l}* \\
* * \\
* \\
* *\end{array}$ \\
\hline $\begin{array}{l}\text { Monmouth } \\
\text { (Ind/Office) }\end{array}$ & $\begin{array}{l}156-742 \\
743-1122 \\
1123-2458\end{array}$ & $\begin{array}{l}1.620-1.746 \\
1.747-2.000 \\
2.001-3.010\end{array}$ & $\begin{array}{l}0.099-0.050 \\
0.050-0.010 \\
0.009-0.000\end{array}$ & $\begin{array}{l}* \\
* * \\
* * *\end{array}$ \\
\hline
\end{tabular}

***Significant at $\alpha=1 \%,{ }^{* *}$ Significant at $\alpha=5 \%,{ }^{*}$ Significant at $\alpha=10 \%$

Table 2 (contd.): Modified R/S Analysis Results: Selected REITs

\begin{tabular}{lllll}
\hline REIT & Lag & $\mathbf{V}_{\mathbf{n}}$ & $\mathbf{p}$ & Sig \\
\hline \multirow{2}{*}{ Cedar Realty } & $140-183$ & $1.622-1.746$ & $0.099-0.050$ & $*$ \\
(Retail) & $184-252$ & $1.747-1.998$ & $0.049-0.010$ & $* *$ \\
& $253-718$ & $2.002-3.370$ & $0.009-0.000$ & $* * *$ \\
Inland & $244-303$ & $1.621-1.746$ & $0.099-0.050$ & $*$ \\
(Retail) & $304-1200$ & $1.748-2.000$ & $0.049-0.010$ & $* *$ \\
& $1201-1987$ & $2.002-2.702$ & $0.009-0.000$ & $* * *$ \\
Urstadt-UBA & $1107-1256$ & $1.620-1.746$ & $0.099-0.050$ & $*$ \\
(Retail) & $1257-1482$ & $1.747-2.000$ & $0.049-0.010$ & $* *$ \\
& $1483-2125$ & $2.001-2.748$ & $0.009-0.000$ & $* *$ \\
\hline
\end{tabular}




\begin{tabular}{lllll}
\hline & $112-169$ & $1.622-1.746$ & $0.099-0.050$ & $*$ \\
Urstadt-UBP & $170-277$ & $1.749-1.747$ & $0.049-0.043$ & $* *$ \\
(Retail) & $278-676$ & $1.745-1.746$ & $0.050-0.050$ & $*$ \\
& $677-1252$ & $1.747-2.000$ & $0.050-0.010$ & $* *$ \\
& $1253-3595$ & $2.001-2.719$ & $0.010-0.000$ & $* *$ \\
\hline
\end{tabular}

${ }^{* * *}$ Significant at $\alpha=1 \%{ }^{* *}$ Significant at $\alpha=5 \% *$ Significant at $\alpha=10 \%$

\section{References}

Alptekin, N. (2008). Rescaled Range Analysis of Turkish Gold Returns. International Journal of Economic Perspectives, 2, 190-198.

Ambrose, B. W., Ancel, E. \& Griffiths, M. (1992). The Fractal Structure of Real Estate Investment Trust Returns: The Search for Evidence of Market Segmentation and Nonlinear Dependency. Journal of the American Real Estate and Urban Economics Association, 20(1), 25-54.

Ambrose, B., Ancel, E. \& Griffiths, M. (1993). Fractal Structure in the Capital Markets Revisited. Financial Analysts Journal, 49(3), 73-77.

Anoruo, E. \& Braha, H. (2010). Testing for Long Memory in REIT Returns. International Real Estate Review, 13, 261-281.

Assaf, A. (2004). Rescaled Variance Analysis of Real Exchange Rates. Applied Economic Letters, 11, 303-306.

Assaf, A. (2006). Canadian REITs and Stock Prices: Fractional Cointegration and Long Memory. Review of Pacific Basin Financial Markets and Policies, 9, 441-462.

Assaf, A. (2008). Long Memory in International Equity Markets: Revisited. Applied Financial Economic Letters, $4,433-437$.

Atiase, R. K. (1985). Predisclosure Information, Firm Capitalization, and Security Price Behavior around Earnings Announcements. Journal of Accounting Research, 23, 21-36.

Baillie, R. T. (1996). Long Memory Processes and Fractional Integration in Econometrics. Journal of Econometrics, 73, 5-59.

Brent, A., Morse, D. \& Stice, E. K. (1990). Short Interest: Explanations and Tests. Journal of Financial and Quantitative Analysis, 25, 273-89.

Caporale, G. M. \& Gil-Alana, L. A. (2010). Multiple Cyclical Fractional Structures in Financial Time Series. Applied Economic Letters, 17, 1079-1081.

Chan, S., Hendershott, P. \& Sanders, A. (1990). Risk and Return on Real Estate: Evidence from Equity REITs. Real Estate Economics, 18, 431-452.

Choi, K. \& Hammoudeh, S. (2009). Long Memory and Oil and Refined Products Markets. The Energy Journal, $30,97-116$.

Chui, A., Titman, S. \& Wei, K. (2003). Intra-Industry Momentum: The Case of REITs. Journal of Financial Markets, 6, 363-387.

Cotter, J. \& Stevenson, S. (2008). Modeling Long Memory in REITs. Real Estate Economics, 36, 533-554.

Connolly, R. A., Güner, Z. N. \& Hightower K. N. (2007). Evidence on the Extent and Potential Sources of Long Memory in U.S. Treasury Security Returns and Yields. Journal of Money, Credit and Banking, 39, 689702.

Cunado, J., Gil-Alana, L. A. \& de-Gracia, F. P. (2010). Persistence in Some Energy Futures Markets. Journal of Futures Markets, 30, 490-507.

D'Avolio, G. (2002). The Market for Borrowing Stock. Journal of Financial Economics, 66(2/3), 271-306.

Derwall, J., Huij, J., Brounen, D. \& Marquering, W. (2009). REIT Momentum and the Performance of Real Estate Mutual Funds. Financial Analysts Journal, 65(5), 11.

Diebold, F. X. \& Rudebusch, G. D. (1989). Long Memory and Persistence in Aggregate Output. Journal of Monetary Economics, 24, 189-209.

Ding, Z., Granger, C. W. J. \& Engle, R. F. (1993). A Long Memory Property of Stock Market Returns and a New Model. Journal of Empirical Finance, 1, 83-106.

Elder, J. \& Jin, H. J. (2009). Fractional Integration in Commodity Futures Returns. Financial Review, 44, 583602.

Glascock, J. L., Lu, C. \& So, R. W. (2000). Further Evidence on the Integration of REIT, Bond, and Stock Returns. 
Journal of Real Estate Finance and Economics, 20(2), 177-194.

Gschwandtner, A. \& Hauser, M. A. (2008). Modeling Profit Series: Non-stationarity and Long Memory. Applied Economics, 40, 1475-1482.

Hays, P., Rajagopal, S. \& Schreiber, M. (2010). Evidence of Long Memory in U.S. Stock Returns: The Case of the 1990s Bubble. Quarterly Journal of Finance and Accounting, 49, 5-18.

Howe, J. S., Martin, D. W. \& Wood, B. G. (1999). Much Ado about Nothing: Long-Term Memory in Pacific Rim Equity Markets. International Review of Financial Analysis, 8(2), 139-151.

Hurst, H. (1951). Long Term Storage of Reservoirs. Transactions of the American Civil Engineers, 2, 770-799.

Jirasakuldech, B. \& Knight J. R. (2005). Efficiency in the Market for REITs: Further Evidence. Journal of Real Estate Portfolio Management, 11(2), 123-132.

Kuhle, J. L. \& Alvayay J. R. (2000). The Efficiency of Equity REIT Prices. Journal of Real Estate Portfolio Management, 6(4), $349-354$.

Kumar, M. S. \& Okimoto, T. (2007). Dynamics of Persistence in International Inflation Rates. Journal of Money, Credit and Banking, 39, 1457-1479.

Lee, M. \& Chiang, K. C. H. (2004). Substitutability between Equity REITs and Mortgage REITs. Journal of Real Estate Research, 26(1), 95-113.

Lin, C. Y., Rahman, H. \& Yung, K. (2009). Investor Sentiment and REIT Returns. Journal of Real Estate Finance and Economics, 39, 450-471.

Ling, D. C. \& Naranjo, A. (1999). The Integration of Commercial Real Estate Markets and Stock Markets. Real Estate Economics, 27(3), 483-515.

Liow, K. H. (2007). The Dynamics of Return Volatility and Systematic Risk in International Real Estate Security Markets. Journal of Property Research, 24, 1-29.

Liow, K. H. (2009). Long Term Memory in Volatility: Some Evidence from International Securitized Real Estate Markets. Journal of Real Estate Finance and Economics, 39, 415-438.

Lo, A. W. (1991). Long-Term Memory in Stock Market Prices. Econometrica, 59(5), 1279-1313.

Mandelbrot, B. B. (1972).Statistical Methodology for Non-Periodic Cycles: From the covariance to R/S analysis. Annals of Economic and Social Measurement, 1, 255-290.

Meade, N. \& Maier, M. R. (2003). Evidence of Long Memory in Short-Term Interest Rates. Journal of Forecasting, 22, 553-568.

Mulligan, R. F. (2000). A Fractal Analysis of Foreign Exchange Markets. International Advances in Economic Research, 6(1), 33-49.

Mulligan, R. F. (2004). Fractal Analysis of Highly Volatile Markets: An Application to Technology Equities. Quarterly Review of Economics and Finance, 44, 155-179.

Mulligan, R. \& Banerjee, D. (2008). Stochastic Dependence in Indian Capital Markets: A Fractal Analysis of the CNX Information Technology Index. Indian Journal of Finance, 2(4), 3-15.

Myer, F. C. N. \& Webb, J. R. (1993). Return Properties of Equity REITs, Common Stocks, and Commercial Real Estate: A Comparison. Journal of Real Estate Research, 8(1), 87-106.

Nelling, E. \& Gyourko J. (1998). The Predictability of Equity REIT Returns. Journal of Real Estate Research, 16(3), 251-268.

Okunev, J., Wilson, P. J. \& Zurbruegg, R. (2000). The Causal Relationship between Real Estate and Stock Markets. Journal of Real Estate Finance and Economics, 21(3), 251-261.

Palmon, D., Sudit, E. F. \& Yezegel, A. (2008). The Accruals Anomaly and Company Size. Financial Analysts Journal, 64, 47-60.

Payne, J. E. \& Waters, G. A. (2007). Have Equity REITs Experienced Periodically Collapsing Bubbles? Journal of Real Estate Finance and Economics, 34, 207-224.

Peter, E. E. (1994). Fractal Market Analysis. John Wiley \& Sons, Inc.

Pyles, M. K. (2009). The Influence of Seasonal Depression on Equity Returns: Further Evidence from Real Estate Investment Trusts. Quarterly Journal of Finance and Accounting, 48, 63-38.

Rajagopal, S. \& Hays, P. (2012). Return Persistence in the Indian Real Estate Market. International Real Estate Review, 15(3).

Sadique, S. \& Silvapulle. P. (2001). Long-Term Memory in Stock Market Returns: International Evidence. International Journal of Finance and Economics, 6, 59-67.

Wang, C. \& Xie, L. (2010). Information Diffusion and Overreaction: Evidence from the Chinese Stock Market. Emerging Markets Finance \& Trade, 46(2), 80-100. 